\title{
Organizational Behaviour in Higher Education Institution: What is the Dominant Factor in Telkom University?
}

\author{
Ida Nurnida $^{1}$, Ai Lili Yuliati ${ }^{2}$, Cut Irna Setiawati ${ }^{3}$, Titin Rini Kartini ${ }^{4}$ \\ 1,2,3,4 Business Administration, Telkom University, Bandung, Indonesia \\ idanurnida@yahoo.com, ailili1955@gmail.com, setiawaticutirna@gmail.com, titinrinikartini@gmail.com
}

\begin{abstract}
Currently the number of Human Development Index (HDI) Indonesia is still very low, ranks 108th out of 187 countries. One of the important steps is of course the increase of Indonesian HDI through education, especially higher education. The World Bank argues that higher education in Indonesia has not been able to deliver the expected results because of institutional university-college still "connected" with other institutional at the core of the system, mainly occur between universities and industry, institutional research, and intercollegiate itself in Research (research). Of the 100 universities, Scopus noted only about 50 productive colleges. There are eight main dimensions of higher education that will be closely related to the institution of related universities, both in the design of formal and informal interaction, including organizational behaviour (organizational behaviour) as one of the important aspects of an institution. Judging from the level of explanation or explanation level, this type of research belongs to descriptive research using quantitative method or approach. The population in this study are all permanent employees of Telkom University. In this research, sampling technique used is Probability Sampling by using Proportionate stratified random sampling. Researchers use sampling designs in probability ways because the sample representation (appropriate sample for investigative research) is important in the context of wider generalizations. Sampling is done after the population is stratified, then the sample members of each strata are drawn using a simple random sampling procedure or systematic sampling. This research uses factor analysis. As a result of this research, only 1 new component is formed in this research which shows that 11 factors used in this research are done entirely on 1 new component that is decision making factor. Which represents the organizational design, leadership, teamwork, ethics and corporate governance, entrepreneurship, job satisfaction, motivation, compensation, selection methods, and communication that describe the important things that Telkom University has in organizing life. Based on the resulting loading factor, decision making factor is the most dominant factor that becomes the power of Telkom University to run its institutional activity as a university.
\end{abstract}

Keywords Organizational behaviour, higher education institution, factor analysis

\section{Introduction}

Currently the number of Human Development Index (HDI) Indonesia is still very low, ranks 108th out of 187 countries, far below HDI neighbouring countries, such as Singapore in 9th place, Brunei Darussalam 30, Malaysia 62, and Thailand 89 . With HDI under the majority of neighbouring countries, it is very difficult for the Indonesian nation to be competitive and "leading" in various areas of life. The enlargement of the quality of Indonesian human beings is much higher if we talk about the current ASEAN Economic Community (AEC) has happened and become part of the global business era that cannot be negotiable.

One of the important steps is of course the increase of Indonesian HDI through education, especially higher education. The World Bank argues that higher education in Indonesia has not been able to deliver the expected results because of institutional university-college still "connected" with other institutional at the core of the system, mainly occur between universities and industry, institutional research, and intercollegiate itself in Research (research). Research is one of the important outputs of universities, which will play an important role in improving the quality of life and welfare of the community.

Quantitatively, the total universities in Indonesia has reached more than 3,500.Namun it turns out that only about 100 universities in Indonesia are recordedScopus or only $2.8 \%$ of all universities in Indonesia. Of the 100 colleges of the ministry, Scopus noted only about 50 productive colleges [1].

Cole stated that "The Great American University" [2], suggests that there are eight major factors that underpin the success of the college in the United States, namely: 1) The combination of teaching and research, 2) autonomy and freedom of the pulpit, 3) Meritocracy and Employment System (tenure system ), 4) peer-review, 5) Competition, 6) 
Talent Influences from around the world, 7) Philanthropy, and 8) Government Funding.

On the other hand, college is one of the institutional set up as rules of the game, both formal and informal, as well as the characteristics of enforcement for reducing risk (reducing risks) and anticipation of uncertainty (uncertainty) Facing due to the bounded capacity (limited capability) and Bounded of information or asymmetric information (the limitations of information) owned by the people who are in it. These institutions include various forms of limitations that are designed or created for each interaction that takes place within the institution of the related universities. The draft can be formal, such as rules or legality arranged humans, or informal, such as a convention or a code of behaviour. The eight main dimensions college stated by Cole will be closely linked to the institutional higher education involving, In the case of formal and informal interaction design, including organizational behaviour (organizational behaviour) as one of the important aspects of an institution.

According to Robbins [3] "Organizational Behaviour (OB) is a field of study that studies the impact of individuals, groups, and structures on behaviour within organizations, for the purpose of applying knowledge for the improvement of organizational effectiveness."

Organizational behaviour examines three determinants of behaviour within the organization, such individual, group, and structure or organization. In short, organizational behaviour is a study of what people do in organizations and how they affect the organization's performance.

Factors organizational behaviour by Robbins \& Judge [4], among others: intelligence, personality, job satisfaction, experience, motivation, pattern Strengthening, Style Leadership, Compensation, Selection Methods, and Organizational Design. Meanwhile, according Luthans [5] factors organizational behaviour among others: Communication, Loading Decision, Stress \& Conflict, Power and Politics, Group \& Team, Design and Objectives Work, Behaviour Management, Process Leadership, Leaders Succeed, and according Zinc \& Ching [5] factors of Organizational Behaviour include: Ethics and Corporate Governance, Leadership, Teams, Creativity, Innovation, Entrepreneurship.

Organizational behaviour is a field of study, an area of expertise separate from the general area of expertise that studies the three general determinants of organizational behaviour: individuals, groups, and structures. In addition, OB applies the knowledge gained about the impact of individuals, groups, and structures on behaviour to make the organization more effective.

In the field of education, the study of organizational behaviour has long been the concern of experts, especially since the organization institutional education is characterized by the involvement of large numbers of people, ranging from educational personnel, educators, students, parents and society. With the complexity of the understanding of the science of organizational behaviour is an important thing, especially for managers in improving the performance of educational organizations. In short, organizational behaviour is a study of what people do in organizations and how they affect the organization's performance.
As an educational institution, Telkom University is required to be able to create and build good organizational behaviour for Higher Education Institution can be run effectively and efficiently considering Education Institution is an institution that aims to develop the human potential of children to be able to perform their duties. The duty of life as a man, both individually and as a member of society. Activities to develop the potential must be done in a planned, directed and systematic in order to achieve certain goals. To achieve the above objectives required an organization of educational institutions. The success of an educational institution can be determined on the basis of a certain criteria. Organizing an educational institution depends on several aspects such as: path, ladder, and the type of organization of the educational institution concerned.

In the era of globalization, educational institutions should be able to print a "leader-leader" is strong and quality. Leaders in the future must be able to change the mindset of getting things done by manpower into mind power. The concept of education should also be able to produce output educational institutions that can create a "corporate culture", so as to adapt to the norms that prevail in that period and in turn grow creativity and initiative, so that the emergence of new opportunities (new opportunity). Output education in the future is also expected to view people not as workers but as partners with different advantages. Thus, a leader out of global competition must be able to view human beings as human beings, not workers.

Based on the above description, the researcher is interested to know the factors of Organizational Behaviour which become the characteristic in Telkom University's Institutional so that the higher education institution can run efficiently and effectively and can achieve the A predicate in such a short period of time.

This research aims to identify organizational behaviour Factors that characterize Telkom University institutions, and the most dominant organizational behaviour factor that characterizes Telkom University's institutions.

\section{Literature Review}

Many opinions about the meaning or definition of the institutions presented by experts, but generally they argue that the institute is formed for reducing risk and uncertainty occurring in social life due to bounded capacity and Bounded of information or asymmetric information that humans have. In defining institutions, it is generally also related to the rule of the game (the "rules of the game") that are made to pro-vide clarity in human interaction.

The diversity of institutional (institutional) definitions by experts is more due to the different perspectives used, related to the issues contexts they are discussing. Alan A. Schmid in his book Conflict and Cooperation - Institutional and Behavioural Economics, defines that (Schmid, 2004: 1) [7]: "Institutions are human relationships that the opportunity structure via constraints and enablement. A constraint on one person is an opportunity for another. Institutions enable individuals to do what they cannot do alone. " 
North's definition of institutions is the rule of the game that exists in society, more formally, are the boundaries that human beings make to interact among themselves in a community, whether political, social, or economic. Further North states that the institution reduces uncertainty by providing structures for everyday life. These structured rules of guides are the guides for interacting with people, for example: greeting friends on the street, driving a car, buying something, borrowing money, shaping business, etc. in our lives, so with the structured rules we can learn by Easy to do (North, 1990: 3-4) [8].

Furthermore, the understanding of the organization and its relationship with the institutions, described North (1990: 4) as follows: "Like institutions, organizations provide a structure to human interaction. Indeed when we examine the costs that arise as a consequence of the institutional framework we see not only the consequences of that framework ".

Conceptually, a clear distinction between institutions and organizations is further explained by North (1990: 4) that institutions are "Rules of the games" or human-made rules with the intent of "organization Is "Rules from the players", which governs the actions or activities of people who gather and interact in a group with the same purpose.

Factors organizational behaviour by Robbins \& Judge (2008: 57) [3], among others: intelligence, personality, job satisfaction, experience, motivation, pattern Strengthening, Style Leadership, Compensation, Selection Methods, and Organizational Design. Meanwhile, according Luthans

(2006) [5], factors organizational behaviour among others: Communication, Loading Decision, Stress \& Conflict, Power and Politics, Group \& Team, Design and Objectives Work, Behavior Management, Process Leadership, Leaders Succeed, and according Zinc \& Ching (2004) factors of Organizational Behavior include: Ethics and Corporate Governance, Leadership, Teams, Creativity, Innovation, Entrepreneurship [7]:

Based on the three references mentioned above, in this research will be tested and analysed 11 factors:

1. Organizational Design, In this study discussed three of several commonly used organizational designs, namely simple structure, bureaucracy and matrix structure. Simple structures are primarily characterized by what is not and not the truth. This structure is not complicated (Mitzberg, 1983: 157). This simple structure has a rendering level of departmentalization, a wide range of controls, centralized authority to a person and a bit of formality [8].

2. Leadership, According to Seng \& Ching (2004), leadership in various companies in Asia emphasizes the flexibility of its business type. In utilizing quality human resources in the Asian region, companies should be more proactive to strengthen the foundation of leader-ship. Companies are also called for more strategic in development and mentoring programs at every level. In addition, companies in Asia also need to develop innovative ways of fostering new leaders in the face of to-day's dynamic business environment in the future [9].

3. Decision Making, According to Robbins \& Judge (2008) [3] decision making is universally defined as an alternative election. This is related to traditional manage- ment function. Most decision-making processes are divided into several steps. Herbert A. Simon conceptualizes three main stages in the decision-making process, namely: (1) intelligence activity, as the stage of tracking environmental conditions requiring decision-making, (2) design activities, as possible stages of discovery, development and problem analysis, and (3) selecting activities, as the stage selects certain actions from those available.

4. Teamwork, The terms group and team become interchangeable. According to Luthans (2005) But the team became very popular in today's organizations, because that's a special concern. The greatest attention to team dynamics and the emergence of cross-functional, virtual and self-managed teams. The cross-functional team consists of individuals from different departments and functions. The key to bringing cross-functional team performance success is in two criteria: one is in the team, and another to the broad organization. The virtual teams now rank in the global world, partnerships and even everyday activities [5].

5. Ethic and Corporate Governance, Ethics and corporate governance (Seng \& Ching, 2004). Ethics is a moral judgment rule created by man and the principles underlying those judgments. While corporate governance is a concept that departs from ethics, and is directly related to the business world, which is about the structure and mechanisms that govern the management of the company so as to produce long-term economic value for sustainable shareholders and stakeholders.

6. Entrepreneurship, Entrepreneurship is the translation of business ideas into profitable business activities. According to Seng \& Ching (2004), the entrepreneurial spirit fostered from the university environment will be a milestone for the revival of entrepreneurial activities in Aisa countries, in particular to inspire and motivate young people to become entrepreneurs [10].

7. Job Satisfaction, According to Robbins \& Judge (2008) job satisfaction as a positive feeling about one's work which is the result of an evaluation of its characteristics. This definition is really a very broad definition. The two most widely used approaches are a single general as-sessment and presentation value End consisting of a number of aspects of the work. Research shows that satisfaction levels undergo many changes, depending on the aspect of job satisfaction discussed.

8. Motivation, increasingly, research on motivation focused on approaches that linked motivational concepts with changes in the way work is compiled. Robbins and Judge (2007) define motivation as a process that explains the intensity, direction and persistence of effort to achieve a goal. Mangkunegara (2005.61) states: "moti-vation is formed from the attitude (attitude) employees in the face of work situations in the company (situation). Motivation is a condition or energy that moves the tar-geted or targeted employees to achieve the goals of the organization.

9. Compensation, Compensation is everything that employees receive as a reward for their work. Compensation is also one of the most effective ways for the per- 
sonnel department to improve job performance, motivation and job satisfaction. Employees, A good compensation system will be able to provide satisfaction for employees and enable companies to acquire, hire, and retain employees. Compensation programs are also important to the company, as they reflect the organization's efforts to maintain its human resources.In addition, compensation is often the most cost component Big and important.

10. Selection Method, According Mardianto (2012) recruitment is a process to get a candidate employees who have the ability in accordance with the qualifications and needs of an organization / company. Byars and Rue (2008) Define Recruitment is Involvement in finding and attracting a number of people who are qualified for existing job vacancies So it can be concluded that recruitment can be interpreted as a process to get employees who have the skills and qualifications required by the company in accordance with vacancy jobs [12].

11. Communication, Communication plays an important role in managerial and organizational effectiveness. Barnard (Luthans: 2005) believes that communication is the main organizing power of the organization. Ac-cording to Barnard, communication makes organiza-tional cooperative system more dynamic and connects organizational goals with all the humans involved in it. There are seven important communication factors for maintaining an organization, including communication channels, formal communication channels, short communications, complete communication channels, people acting as communications centres, communications channels that do not interfere with the functioning of the organization and authenticated communications [5].

\section{Methodology}

Judging from the level of explanation or explanation level, this type of research belongs to descriptive research using quantitative method or approach. Population in this research is All employee of Telkom University 1029 people. In this research, sampling technique used is Probability Sampling by using Proportionate stratified random sampling. Ac-cording to Sekaran (2010: 270) [13] Probability Sampling is a sampling technique where the magnitude of probability or probability of elements in the population to be selected as the subject of the sample is known. Researchers use sampling designs in probability ways because the sample representa-tion (appropriate sample for investigative research) is im-portant in the context of wider generalizations. Given the number of population in this study is known, then to deter-mine the number of samples to be used in this study re-searchers used the formula Slovin (Prasetyo and Jannah, 2012: 138). Based on the results of the sample count, ob-tained the number 99.98 for the minimum number of samples, but the author rounded up to 100 respondents to reduce the error filling questionnaire [14].
Table 1. Detail of Sample

\begin{tabular}{|l|c|c|c|}
\hline JABATAN & POPULASI & PERHITUNGAN & SAMPEL \\
\hline Rektorat & 5 & $5 / 1029 \times 100=0.4859$ & 1 \\
\hline Dekanat & 19 & $19 / 1029 \times 100=1.846453$ & 2 \\
\hline Direktur & 13 & $13 / 1029 \times 100=1.263362$ & 2 \\
\hline Kaprodi & 29 & $29 / 1029 \times 100=2.81827$ & 3 \\
\hline Sekprodi & 11 & $11 / 1029 \times 100=1.068999$ & 2 \\
\hline Manajer & 30 & $30 / 1029 \times 100=2.915452$ & 3 \\
\hline Kaur & 86 & $86 / 1029 \times 100=8.357629$ & 9 \\
\hline Staff & 242 & $242 / 1029 \times 100=23.517$ & 24 \\
\hline Dosen & 594 & $594 / 1029 \times 1029=57.725$ & 58 \\
\hline
\end{tabular}

This research uses Factor Analysis technique. Factor analysis is a type of analysis used to recognize the underlying dimensions or regularity of a phenomenon. The general purpose of factor analysis is to summarize the variable con-tent of large amounts of information into a number of smaller factors (Kuncoro, 2003: 241). Perform core processes on factor analysis ie factoring, or deriving one or more factors from the variables that have passed in the previous variable test [14].

Factoring process is used to determine the new factors that are formed. This study uses Principal Component Analysis (PCA) using the total variance that produces the smallest specific and error variance. In determining the new factor can be done by looking at the value of eigenvalue.Component which has eigenvalue $\geq 1$ is the component used. The\% Cumulative column shows the percentage of variance that can be explained by the factor.

\section{Result and Discussion}

Based on the description analysis, obtained a number of data about the respondents. Of the 103 respondents studied were female (47\%), while male gender was $56(54 \%)$. This shows that men's social status has an obligation to work and earn income compared to women. Based on recent education, 4 people (4\%) Telkom University employees have high school education, 4 people (4\%) others are educated D3, 16 people (16\%) have S1 degree, 61 people (59\%) have S2 degree, and 18 (17\% ) Has completed his doctoral education. Based on the data, it can be concluded that the majority of Telkom University employees have recent education S2. This is because most of the employees are lecturers whose minimum education requirement is S2 (Master). Based on the position, shows that based on sampling technique using Propotionate stratified random sampling which is a sampling technique used when the population has members or ele-ments that are not homogeneous or stratified proportionally, it can be seen that the respondent consists of 1 person (1\%) Rectorate, 2 Person (2\%) Dean, 2 persons (2\%) Director, 3 persons (3\%) Head of Study Program, 2 persons (2\%) Sec-retary of Study Program, 3 persons $(3 \%)$ Manager, 8 persons 
(8\%) Head Affairs, 24 (23\%) Staff, and 58 people (56\%) Lecturers. Based on the length of work, it shows that from 103 respondents it can be seen that as many as 46 people (45\%) have worked for 1-5 years, as many as 28 people (27\%) have worked for 6-10 years, as many as 10 people (10\%) have Worked for 11-15, and 19 people (18\%) have worked for more than 15 years at Telkom University. Based on age, from 103 respondents it can be seen that employees under the age of 25 are 4 people (4\%), employees aged 2535 years amount to 49 people (48\%), employees aged 36-45 years amounted to 24 people ( $23 \%$ ), Employees aged 46-55 years amounted to 18 people (17\%), and employees aged over 55 years amounted to 8 people $(8 \%)$. This illustrates that the majority of Telkom University employees are at the pro-ductive age of 25-35 years old.

Factor analysis was used to identify organizational behavior factors on higher education institution in West Java with study at Telkom University which will show the existence of dominant factors. Processing factor analysis is done by using Statistical Program of Social Science (SPSS) version 20 for windows. Total factors in this study amounted to 11 factors with 29 statements which then analyzed using factor analysis.

After all process, here is the result Component Matrix. Component matrix aims to show the distribution of variables on the components formed based on the loading factor. Dis-tribution of variables that become criteria in component matrix can be seen based on loading factor that has correla-tion value> 0,5. The larger the loading factor, the more ob-vious the variable can be included in one of its components, and vice versa. The component matrix table can be seen in the following tables:

Table 2. Component Matrix

\begin{tabular}{|l|c|}
\hline \multicolumn{1}{|c|}{ Variabel } & Component \\
\cline { 2 - 2 } & 1 \\
\hline Desain Organisasi & 0,720 \\
\hline Leadership & 0,665 \\
\hline Pengambilan keputusan & 0,804 \\
\hline Teamwork & 0,715 \\
\hline Ethics \& Corporate Governance & 0,654 \\
\hline Entrepreneurship & 0,659 \\
\hline Kepuasan Kerja & 0,779 \\
\hline Motivasi & 0,801 \\
\hline Kompensasi & 0,657 \\
\hline Metode Seleksi & 0,736 \\
\hline Komunikasi & 0,666 \\
\hline
\end{tabular}

Based on table 4.5 it can be seen that the initial 11 factors that exist will enter into component 1 (new factor). This is because in this study only formed 1 new component. In the component matrix process, if there is a correlation value $<0.5$, then re-rotation should be performed. Conversely, if the correlation value is $>0.5$, then no re-rotation is necessary. Factor rotation is done to make the big correlation value bigger and the smaller correlation value becomes smaller. Thus, the difference in correlation value will become clearer after the factor rotation (Santoso, 2014: 61). From table 4.5 shows that the eight variables have a correlation value> 0.5 which means no rotation factor is necessary,

Based on the table 4.5, it is known that 11 factors are sequentially based on the highest loading factor, namely: decision making of $80.4 \%$, motivation $80.1 \%$, job satisfaction of $77.9 \%$, selection method of $73.6 \% 72,0 \%$, teamwork $71,5 \%$, communication $66,6 \%$, leadership $66,5 \%$, entrepreneurship 65,9\%, 65,7\% compensation, and ethics and corporate governance $65,4 \%$.

After grouping of factors, the next step is the process of naming the factors (labeling) is to give the name of the new component that is formed and is considered capable of representing the variables that are in it. Based on the results of data processing Total Variance Explainer I (Table 4.4), it can be seen that from 11 initial factors that exist, only 1 new component is formed. Naming of components is based on the highest loading factor of the factors that have been formed. The component is called decision making because it has the largest loading factor $(80.4 \%)$ and this component consists of organizational design, leadership, teamwork, ethics and corporate governance, entrepreneurship, job satisfaction, motivation, compensation, selection method, and commu-nication Important that owned by Telkom University in running organizational life.

\section{Conclusion}

Based on the result of factor analysis, there is 1 new component that is Decision Making, representing organizational design factor, leadership, teamwork, ethics and corporate governance, entrepreneurship, job satisfaction, motivation, compensation, selection method, and communication which describe important thing owned by Telkom University in running organizational life.

Based on the resulting loading factor, decision making factor is the most dominant factor that becomes the power of Telkom University to run its institutional activity as a uni-versity. This shows that Telkom University has analyzed the external and internal environment as the basis of decision making and always involves all parties in the process so that the decisions taken are known and understood by all aca-demic community comprehensively.

As a suggestion, for the factors that get the lowest response is the factor ethics and corporate governance of $65.4 \%$. Telkom University to be able to create a consistent business ethics standard in accordance with the rules of the Government (RISTEK DIKTI) in order to maintain the ethical sustainability and quality of education services provided to external and internal parties.

\section{ACKNOWLEDGEMENT(S)}

This research conducted by lecturer team of Business Administration and supported by Research Centre of Telkom University. Authors would like thank to colleagues, students and all academic partners who spare their valuable time to 
support this research, throughout direct and indirect support such filled the questionnaires.

\section{REFERENCES}

[1] Gunawan, "Perguruan Tinggi Indonesia Paling Produktif Menurut Scopus", [Online], Available at: http://personal.fmipa.itb.ac.id/hgunawan/2015/01/28/50-perg uruan-tinggi-indonesia-paling-produktif-menurut-scopus-20 15. [access at $2^{\text {nd }}$ October 2015]

[2] Salgado JF, Anderson N, Moscoso S, Bertua C, Fruyt F, Rolland JP, "A Meta Analyticac Study of General Mental Ability Validity for Different Occupations in the European Community", Journal of Applied Psychology, pg. 10681081, 2003.

[3] Robbins, Stephen P. dan Timothy A. Judge. 2008. "Perilaku Organisasi”, Ediction 12, Jakarta: Salemba Empat, 2008.

[4] Robbins, Stephen P. dan Timothy A. Judge, "Perilaku Organisasi”, Ediction, Jakarta: Salemba Empat, 2015.

[5] Luthans, Fred. 2006. Perilaku Organisasi, (Alih Bahasa V.A Yuwono, dkk), Edisi Bahasa Indonesia, Yogyakarta: ANDI.

[6] Kirkman B, Rosen B, Gibson C, Teslik P, McPherson S. 2002. Five Challenges to Virtual Team Success: Lesson from Sabre. Academy of Management Executives, vol 16(3).

[7] Mathis, Robert L., dan John H., Jackson. 2006. Human Resource Management: Manajemen Sumber Daya Mamnusia. Alih Bahasa: Diana anggelica. Jakarta: Salemba empat.

[8] Mintzberg H. 1983. Structure in Fives: Designing Effective Organizations. Upper Saddle River, NJ: Prentice Hall.

[9] Riggio RE, Murphy SE, Pirozzolo FJ. 2002. Multiple Intellegences and Leadership. Mahwah, NJ: Lawrence Erlbaum.

[10] Salgado JF, Anderson N, Moscoso S, Bertua C, Fruyt F, Rolland JP. 2003. A Meta Analyticac Study of General Mental Ability Validity for Different Occupations in theEuropean Community. Journal of Applied Psychology, pg. 1068-1081.

[11] Nawawi, Hadari. H, Prof,Dr, 2008, Manajemen Sumber Daya Manusia, Gajah Mada University Press, Yogyakart.

[12] Seng JT, Ching C. 2004. Organizational Behavior in Asia. McGraw Hill: Singapore.

[13] Sekaran, Uma \& Bougie, Roger. (2010). Research Method for Business A Skill Building Approach ( $5^{\text {th }}$ Edition). United Kingdom: John Wiley \& Sons Ltd.

[14] Wexley, Kenneth. M. And Gary A. Yuki. 2005. Perilaku Organisasi dan Psikologi Personalia.Rineka Cipta: Jakarta.

[15] Winardi. J. 2002. Motivasi dan Pemotivasian dalam Manajemen. Rajawali Pers: Jakarta. 